\title{
Can the High Quality of Internal Control Promote the Fulfillment of Corporate Social Responsibility in Energy Enterprises?
}

\author{
Yunchen Wang \\ School of Management \\ Sichuan Agricultural University \\ Chengdu, China \\ E-mail:wangyc8684@qq.com
}

\author{
Manping Tang \\ School of Management \\ Sichuan Agricultural University \\ Chengdu, China \\ E-mail: tangmanping429@126.com \\ Corresponding Author
}

\author{
Xuan Yu \\ Business School \\ Sichuan University \\ Chengdu, China \\ E-mail:yuxuan_0917@aliyun.com \\ Corresponding Author
}

\begin{abstract}
It's an inherent requirement for the energy enterprises to effectively fulfill their corporate social responsibility in order to realize their sustainable development along with the society. Taking the listed corporations in energy industry as the research samples, this paper analyzed the influence of internal control quality on corporate social responsibility. The study drew the following conclusions: Based on the stakeholder theory, the fulfillment of energy enterprises' social responsibility could be evaluated from various levels, like shareholders, government, customers and employees. The high quality of internal control significantly promoted the fulfillment of corporate social responsibility in the levels of shareholders and government, but it was not so significant in the levels of customers and employees. These conclusions have provided theoretical guidance for the energy enterprises to upraise their internal control quality and to facilitate their fulfillment of corporate social responsibility in view of different stakeholders. Besides, direct evidence support has also been offered for the practical application of "Application Guidance for Enterprise Internal Control -- Social Responsibility" and "Operation Guidance for the Internal Control of Petroleum and Petrochemical Industry”.
\end{abstract}

Keywords-energy enterprises; internal control; corporate social responsibility

\section{INTRODUCTION}

Enterprise is not only an important carrier of market economy, and also a significant part of social production and distribution unit. Corporate social responsibility is the social obligations in the process of enterprises' operation and development. It is related to various stakeholders, Such as the interests of shareholders, the equity of customers, and the welfare of employees. It's an inherent requirement for the energy enterprises to effectively fulfill their corporate social responsibility in order to realize their sustainable development along with the society. Energy enterprises play a fundamental and leading role in the national economy, and often involve all aspects of economic and social life. Therefore, whether the energy enterprises' fulfillment of corporate social responsibility is effective or not often functions profoundly on the society. For example, occurring in June, 2011, the oil spill accident of Penglai 19-3 Oilfield, Bohai ConocoPhillips, has aroused some significant effects on aquaculture, tourism, ecology and so on. This accident has caused a total of 5,500 square kilometers of sea pollution. According to the report in Chinese Energy News on November 14, 2012, the survey by Chinese Institute of Energy Economics demonstrated that only 16\% of the top 500 energy enterprises in China had issued the corporate social responsibility report, indicating their weak awareness of corporate social responsibility.

Aiming at the problems, such as the weak awareness of corporate social responsibility, As the director in the research center of corporate social responsibility in Chinese Institute of Energy Economics, Chinese energy enterprises should strengthen their fulfillment of corporate social responsibility from many perspectives, like the responsibilities for enterprises' development, for employees, customers, public relations, etc [1].The stakeholder theory also suggests that enterprises should consider the demands of stakeholders, such as shareholders, employees, government, customers, et al. in the process of operation and management, which is the most basic starting point for understanding the corporate social responsibility [2]. In order to further enforce the fulfillment of corporate social responsibility during the enterprises' development, the ministry of finance and other four national ministries specially formulated "Application Guidance for Enterprise Internal Control -Social Responsibility" [3] based on the "Basic Norms of Enterprise Internal Control". Directing at the current weak links in the fulfillment of corporate social responsibility, they also teased out some crucial risk points and proposed countermeasures. Furthermore, 
taking it into account that the petroleum and petrochemical industry shoulders corporate social responsibility of ensuring the national energy security and providing power for the economic development, in 2013 the ministry of finance also specially formulated the "Operation Guidance for the Internal Control of Petroleum and Petrochemical Industry" [4]. It indicated that it was the basic premise and criterion in the production and operation and achievement of sustainable development for the petroleum and petrochemical enterprises to strengthen their internal control and fulfill their corporate social responsibility. Since then, a security system of internal control construction and implementation in Chinese energy enterprises has been established. Thus, how about the current status of Chinese energy enterprises' performance of corporate social responsibility in view of different stakeholders? As for the different stakeholders, whether the internal control quality would promote the performance of corporate social responsibility? These issues deserve our in-depth study.

\section{THEORETICAL ANALYSIS AND RESEARCH HYPOTHESES}

According to the stakeholder theory, Kavasseri considered that the corporate social responsibility included 4 categories: customers, employees, communities and vulnerable groups [5]. The World Business Council for Sustainable Development pointed out that the corporate social responsibility should cover the employees' rights and interests, environmental protection, community participation, and so on [6]. Zhou Guodong based on Clarkson's research, suggested that the stakeholders should be divided into main stakeholders and secondary stakeholders. He also evaluated the enterprise stakeholders' fulfillment of corporate social responsibility from the levels of shareholders, customers, government and employees [7].

Corporate social responsibility has surpassed the previous category that the enterprises are only responsible for their shareholders, and it emphasizes the responsibility for the stakeholders, including shareholders, employees, customers, and government [3]. The "Operation Guidance for the Internal Control of Petroleum and Petrochemical Industry" [4] has pointed out that, oil and other energy enterprises' present corporate social responsibility mainly includes the responsibility in safety production, product quality, and the protection of employees' rights and interests. The weak links and exposed risks during the energy enterprises' fulfillment of their corporate social responsibility are mainly as the following points: (1) Many factors, such as the inadequate measures for safety production, the weak awareness of responsibility and the unsound rewards and punishment mechanism, may cause safety accidents. Especially, the energy industry is of high-risk. Once the accident happens, the shareholders' interests would be greatly damaged, and it is also highly likely to affect other industries, thereby disturbing the normal operation of economy and society. (2) Generally, with tremendous trade amount and profits, the energy enterprises may be involved in tax evasion, leading to the lack of social responsibility in the government level. For instance, according to the report in China News Net on October 12, 2011, the ministry of finance announced that the subsidiary of Sinopec had been detected for the tax evasion of tens of millions. (3) The relaxed management control of product quality, the ignorance of the protection of customers' value, and the infringement of customers' interests, would lead to the damage on enterprises' value and image or even bankruptcy. (4) With the violation of their personal rights but without the supply of a reasonable compensation to guarantee their work, the employees' enthusiasm could not be effectively stimulated.

With regard to the potential risks existing in the performance of corporate social responsibility in energy enterprises, as is mentioned above, the enterprises' internal control measures adopted are as follows: (1) It is effective measure to establish regulations and system, to perfect the management organization for safety production, to intensify the input in safety production and regular maintenance management, to build the normal mechanism of leaders being grass-roots and accountability mechanism, and to set up the early security warning and report system via modern information technology. (2) It is effective measure to strengthen the comprehensive quality management, to enable the staff to aware that product quality is the lifeline of enterprises' sustainable development, to establish product quality standard and traceability system, to refine the procedures and system of control and inspection as well as the products' after-sale service. (3) It is effective measure to establish a scientific and reasonable growth mechanism of staff compensation and to standardize the staff training and promotion system. (4) It is effective measure to familiarize with tax laws and regulations, to update timely the tax knowledge, to build the communication mechanism with the tax authority, to hire intermediary institutions for periodically assessment of tax risks, and to propose improvement measures and real-time trace evaluation. From the foregoing, the establishment and effective implementation of enterprises' internal control system could ensure the fulfillment of corporate social responsibility.

Based on the above analysis, this paper puts forward the following hypothesis:

Hypothesis 1: enterprises' internal control quality has promoted the shareholders' fulfillment of social responsibility.

Hypothesis 2: enterprises' internal control quality has promoted the government's fulfillment of social responsibility.

Hypothesis 3: enterprises' internal control quality has promoted the customers' fulfillment of social responsibility.

Hypothesis 4: enterprises' internal control quality has promoted the employees' fulfillment of social responsibility.

\section{RESEARCH DESIGN}

\section{A. Sample selection and data sources}

Consulting the about the Classification of China Securities released by China securities index Co., Ltd, the Shanghai energy industry index constitute stock list, the industry classification standard of listed company made by CSRC and the samples used in Zhou Guodong [7], this paper selected the listed companies of energy industry as researching samples and also took the Basic Standard for 
Enterprise Internal Control and its auxiliary guidelines into consideration. Considering "the enterprise basic internal control norms" is published in 2008, the samples selected in this paper are all non-financial A-share listed companies from 2008 to 2013. After eliminating ST or PT and companies whose data is seriously missed, finally there remains 236samples. In addition, "The Chinese listed company internal control index" comes from Shenzhen DI BO enterprise risk management technology co., ltd., and the rest data is from CSMAR database.

Measurement for the fulfillment of corporate social responsibility. According to the "Guidance for Listed Corporations' Social Responsibility” issued by Shenzhen Stock Exchange in 2006, the social responsibility of listed corporations refers to these corporations' responsibility for the comprehensive development of the country and society, for the natural environment and resources, and for the stakeholders like shareholders, employees, customers and communities. Based on the stakeholder theory and with reference to the evaluation of Zhou Guodong [7], we have divided the corporate social responsibility into four parts: the fulfillment of social responsibility in the shareholders' level (CSROW), the fulfillment of social responsibility in the government's level (CSRGV), the fulfillment of social responsibility in the staff's level (CSRSF), the fulfillment of social responsibility in the customers' level (CSRCT).The specific definitions are seen in table1.

Proxy variables reflecting the quality of internal control. According to the interpretation of "The enterprise internal control evaluation guide-lines "by accounting department of the ministry of finance and, the quality of internal control refers to the reasonable assurance that the establishment and implementation of enterprise internal control provide for the achievement of controlling objectives. Thus it can be seen that the quality of the internal control system can be measured by the achieving situation of internal control strategies, management, reports, compliance and assets security [8]. "DI BO-The Chinese listed company internal control index" launched by Shenzhen DI BO enterprise risk management technology co., ltd. covers the execution results of the enterprise strategy (market share and risk coefficient), return (return rate and net profit margin of invested capital), the authenticity and integrity of information disclosure (the audit opinions and the financial restatement), the compliance legality (laws and regulations violation as well as lawsuit), asset security (asset value maintenance and improvement).It also supplies and corrects the defects of internal control. In fact, this index reflects the main part of enterprise internal control goals, and it is also the manifestation of effective implementation of the internal control. Therefore, we should choose this index as the proxy variable to reflect the quality of internal control. The specific definitions are seen in table1.

\section{B. Test model and illustration of relevant variables}

In order to test the hypotheses, we have established the following model (1).

$$
\begin{aligned}
C S R_{i t}= & \beta_{0}+\beta_{1} I C_{i t}+\beta_{2} L E V_{i t}+\beta_{3} C F P S_{i t}+\beta_{4} D U A L_{i t} \\
& +\beta_{5} I N D R A_{t t}+\beta_{6} Z_{H S H A}+\sum Y E A R_{i t}+\varepsilon_{i t}
\end{aligned}
$$

Among them, the dependent variable is the performance of corporate social responsibility (CSR). Based on the stakeholder theory, the fulfillment of corporate social responsibility could be divided into four parts: CSROW, CSRGV, CSRSF, and CSRCT. The variable to be researched is the quality of internal control (IC). The higher the index is, the more effective the internal control will be. In addition, from the previous researches by Gao Jingzhong and Zhou Xiaosu [9], and Feng Lili et al [10], we also control the factors like LEV, CFPS, DUAL, INDRA and ZHSHA. The definitions of

\begin{tabular}{|c|c|c|}
\hline Variable & Symbol & Variable Definition \\
\hline \multirow{4}{*}{$\begin{array}{l}\text { Dependent } \\
\text { Variable }\end{array}$} & CSROW & $\begin{array}{l}\text { Basic earnings per share: the enterprises should } \\
\text { belong to the common shareholders' current net } \\
\text { profit / the number of ordinary shares. }\end{array}$ \\
\hline & CSRGV & Income tax expense / total revenue. \\
\hline & CSRSF & The cash paid to and for employees / total revenue. \\
\hline & CSRCT & $\begin{array}{l}\text { (current year revenue -last year revenue)/ last year } \\
\text { revenue. }\end{array}$ \\
\hline $\begin{array}{l}\text { Independent } \\
\text { Variables }\end{array}$ & IC & $\begin{array}{l}\text { Reflected by the effectiveness of IC, standardized by } \\
\text { dividing the DI BO, China listed company internal } \\
\text { control index with } 100 \text {. }\end{array}$ \\
\hline \multirow{5}{*}{$\begin{array}{l}\text { Control } \\
\text { Variables }\end{array}$} & LEV & Asset-liability ratio. \\
\hline & CFPS & $\begin{array}{l}\text { Enterprises' free cash flow per share: (net increase } \\
\text { of cash and cash equivalents - net cash flow } \\
\text { generated from financing activities) the current } \\
\text { value / paid-up capital of the current final value. }\end{array}$ \\
\hline & DUAL & $\begin{array}{l}1 \text { represents the combination of general manager and } \\
\text { the chairman of the board. 0stands the opposite. }\end{array}$ \\
\hline & INDRA & $\begin{array}{l}\text { Independent director number/the number of the } \\
\text { board of directors. }\end{array}$ \\
\hline & ZHSHA & $\begin{array}{l}\text { The proportion of first shareholder and second } \\
\text { shareholder. }\end{array}$ \\
\hline
\end{tabular}
main variables are seen in table I.

\section{TEST RESULTS AND ANALYSES}

\section{A. Descriptive statistics}

The descriptive statistics of main variables are given in table II. This paper has evaluated the fulfillment of corporate social responsibility from four levels. Specifically, the Mean of CSROW is 0.6026, and the Min and Max are -1.9000 and 2.9900 respectively. With the Mean being 0.0268 , the SD of CSRGV is 0.0263 , and the Min and Max are -0.0301 and 0.2013 respectively. The Max and Min value of CSRSF are 0.5091 and 0 . With the Mean being 0.4963 , the Min and Max of CSRCT are 0.6341 and 38.1197 respectively. All these above show that the social responsibility fulfillment acts different in different levels among different enterprises. Besides, in terms of IC, the Mean is 6.8130, the SD is 1.2988 and the Max is 9.9536 of 10 , demonstrating that the IC in the listed companies of energy industry lies above the average level. Moreover, this paper also has taken the VIF of different variables into calculation, which are all below 2, neglecting the possibility of multicollinearity.

\begin{tabular}{|c|c|c|c|c|c|c|}
\hline Variable & $\mathbf{N}$ & Mean & SD & Median & Min & Max \\
\hline CSROW & 236 & 0.6026 & 0.7340 & 0.4536 & -1.9000 & 2.9900 \\
\hline CSRGV & 236 & 0.0268 & 0.0263 & 0.0208 & $\begin{array}{l}-0.0301 \\
\end{array}$ & 0.2013 \\
\hline CSRSF & 236 & 0.1479 & 0.1145 & 0.1195 & 0.0000 & 0.5091 \\
\hline CSRCT & 234 & 0.4963 & 2.6966 & 0.1252 & -0.6341 & 38.1197 \\
\hline IC & 236 & 6.8130 & 1.2988 & 6.9138 & 0.0000 & 9.9536 \\
\hline LEV & 236 & 0.4904 & 0.1743 & 0.5040 & 0.0071 & 0.8868 \\
\hline CFPS & 236 & $\begin{array}{l}-0.4733 \\
\end{array}$ & 2.2493 & 0.0653 & -11.1767 & 3.6978 \\
\hline DUAL & 236 & 0.1102 & 0.3138 & 0.0000 & 0.0000 & 1.0000 \\
\hline INDRA & 236 & 0.3631 & 0.0558 & 0.3333 & 0.2222 & 0.7143 \\
\hline ZHSHA & 236 & 26.6796 & 40.9951 & 9.7153 & 1.0717 & 365.5322 \\
\hline
\end{tabular}

TABLE II. THE DESCRIPTIVE STATISTICS OF MAIN VARIABLES 


\section{B. Regression analysis}

Seen in table III, the model (1) has been tested by analyzing the impact of corporate IC on the enterprises' fulfillment of social responsibility in different layers. In the regression 1, the regression coefficient of IC on CSROW is $0.1774(\mathrm{P}<0.01)$. In the regression 2 , the regression coefficient of IC on CSRGV is 0.0031 $(\mathrm{P}<0.05)$. However, in the regression 3 and 4 , the coefficients of IC on CSRSF and CSRCT are not significant, proving that in energy industry the corporate IC can only facilitate the shareholders' and government's fulfillment of corporate social responsibility but not that of staff and customers. Therefore, only the hypotheses 1 and 2 have been verified, while the hypotheses 3 and 4 have not.

TABLE III. TEST ON THE IMPACT OF IC ON THE FULFILLMENT OF CORPORATE SOCIAL RESPONSIBILITY: BASED ON EVALUATION OF DIFFERENT STAKEHOLDERS

\begin{tabular}{|c|c|c|c|c|}
\hline \multirow{3}{*}{ Variable } & \multicolumn{4}{|c|}{ Dependent variable } \\
\hline & CSROW & CSRGV & CSRCSF & CSRCT \\
\hline & regression 1 & regression 2 & regression 3 & regression 4 \\
\hline \multirow{2}{*}{ IC } & $0.1774 * * *$ & $0.0031 * *$ & -0.0116 & 0.0612 \\
\hline & $(4.2905)$ & $(2.0842)$ & $(-1.5768)$ & $(0.7488)$ \\
\hline \multirow[t]{2}{*}{ LEV } & $-0.5719^{* *}$ & $-0.0251 * * *$ & $-0.1051^{* *}$ & $1.2767^{* *}$ \\
\hline & $(-2.2584)$ & $(-2.7304)$ & $(-2.3308)$ & $(2.4220)$ \\
\hline \multirow[t]{2}{*}{ CFPS } & 0.0228 & -0.0003 & -0.0037 & 0.0484 \\
\hline & $(0.9914)$ & $(-0.3757)$ & $(-1.0122)$ & $(0.5204)$ \\
\hline \multirow[t]{2}{*}{ DUAL } & $-0.2540^{*}$ & $-0.0113^{* *}$ & $-0.0734^{* * *}$ & -0.3675 \\
\hline & $(-1.6683)$ & $(-2.1158)$ & $(-3.6328)$ & $(-1.5428)$ \\
\hline \multirow[t]{2}{*}{ INDRA } & $-0.8672 *$ & -0.0289 & -0.1639 & -0.6587 \\
\hline & $(-1.7116)$ & $(-1.2608)$ & $(-1.5854)$ & $(-0.8087)$ \\
\hline \multirow[t]{2}{*}{ ZHSHA } & 0.0006 & 0.0000 & $0.0008^{* * *}$ & -0.0003 \\
\hline & $(0.8429)$ & $(0.3749)$ & (4.2529) & $(-0.2346)$ \\
\hline \multirow[t]{2}{*}{ CONS } & 0.2490 & $0.0347^{* *}$ & $0.2959 * * *$ & -0.2552 \\
\hline & $(0.7138)$ & $(2.4184)$ & $(3.5626)$ & $(-0.3845)$ \\
\hline YEAR & CONTROL & CONTROL & CONTROL & CONTROL \\
\hline $\mathrm{R}^{2}$ & 0.2271 & 0.1229 & 0.1625 & 0.1370 \\
\hline $\mathrm{F}$ & $4.64^{* * *}$ & $2.78^{* * *}$ & $3.56 * * *$ & $4.76^{* * *}$ \\
\hline OBS & 236 & 236 & 236 & 234 \\
\hline
\end{tabular}

\section{ROBUST TESTS}

Considering the fact that the measurement of the fulfillment of corporate social responsibility from the angle of different stakeholders may cause conclusion bias, we have referred to the evaluation methods for the fulfillment of corporate social responsibility from different levels by Gao Jingzhong and Zhou Xiaosu [9], Feng Lili et al. [10]. Then the hypotheses involved in this paper have been re-examined, but there is almost no change in the research conclusions. Considering the potential negative influence of extreme value in variables and the limitation of samples, this paper has $0.5 \%$ of Winsorize on each variable and has redone multiple regression analysis. The results still stay the same.

\section{RESEARCH CONCLUSIONS AND ENLIGHTENMENT}

In recent years, the energy industry plays a growing important role in our national economic and social development, which also arouses more and more concern on its fulfillment of social responsibility. At the same time, being non-renewable and potentially polluting, energy industry also goes with risks. In order to control the risks efficiently, our government successively released
"Application Guidance for Enterprise Internal Control -Social Responsibility" [3] and "Operation Guidance for the Internal Control of Petroleum and Petrochemical Industry" [4]. Under this background, this paper exemplified on the listed companies in energy industry, analyzing the effects impacts of internal control on corporate social responsibility in the angle of stakeholders. The research has found that the corporate IC could only promote the shareholders' and government's fulfillment of social responsibility but not that of staff and customers, which means that the impacts differentiate among different stakeholders, probably owing to their different interests demands and other aspects. Frooman [11] has indicated that the fulfillment of corporate social responsibility would be enhanced on the condition of shareholders' wealth increase, which has laid foundation to the performance of social responsibility in rational egoism corporate. Schwartz and Carroll [12] believed that the motivations for the fulfillment of corporate social responsibility include economy, system and morality. Gao Jingzhong and Zhou Xiaosu [9] pointed out that, in reality, the rational enterprises were impossible to fulfill their social responsibility solely depending on the moral motivation, but the economy was the real backbone. Under the system where government intervenes economy and big shareholders take the dominant role, compared to the staff and customers, the rational enterprises are more inclined to meet the government's and shareholders' demands first in their performance of social responsibility.

The research results in this paper provide a theoretical instruction to enhance internal control and strengthen the fulfillment of corporate social responsibility according to different stakeholders. On the one hand, the construction and effective operation of internal control can ensure the fulfillment of social responsibility in the levels of government and shareholders. Hence, the energy industry should strengthen the establishment of internal control system. On the other hand, although internal control cannot obviously increase the social responsibility of staff and customers, considering their important function in enterprise development, the energy enterprises should take effective measures to stimulate their fulfillment of social responsibility corresponding to their social responsibility risks. Besides, the research results in this paper also present some direct evidence to the practical application of "Application Guidance for Enterprise Internal Control -- Social Responsibility" [3] and "Operation Guidance for the Internal Control of Petroleum and Petrochemical Industry" [4].

\section{ACKNOWLEDGEMENTS}

We are deeply grateful for the support from Humanitie s \&Social Sciences Research Fund of the Ministry of Educ ation: the effectiveness of internal control in state-owned enterprises based on the angle of political connection and CEO incentive (project approval number: 14YJC630135) and the support from the 2014 Annual Project of Sichuan Agricultural University German Research Center of Sichuan Philosophy Society and Science Key Research Base(project approval number: ZDF1404),Director: Yunchen Wang. 


\section{REFERENCES}

[1] Y. D. Liu, "Energy companies should be strengthened sense of social responsibility,” Chinese Energy Newspaper, vol.11, 2012.

[2] R. L. Yang and Y. A. Zhou, "Stakeholder theory and its application (The first edition). Beijing: Economic Science Press, 2000.

[3] The Accounting Department of the Ministry of Finance, the Explanation Basic Standard for Enterprise Internal Control, Economic Science Press, 2010.

[4] The Accounting Department of the Ministry of Finance, Operation Guidance for the Internal Control of Petroleum and Petrochemical Industry, 2013.

[5] V.R. Kavasseri, "Toward a theory of corporate social accounting,” The Accounting Review, vol.10, 1976, pp.516-528.

[6] World Business Council for Sustainable Development, Corporate Social Responsibility: The WBCSD’s journey, 2002.

[7] G. D. Zhou, "Analysis of the correlation between social responsibility and financial performance in energy enterprise," Modernization of Management, vol.6, 2012, pp.88-90.
[8] Chinese listed company internal control index research group, Chinese listed company internal control index research. Accounting Research, vol.12, 2011, pp.20-24.

[9] J. Z. Gao and X. S. Zhou, "Operating performance, ultimate controller and degree of social responsibility fulfillment," Collected Essays on Finance and Economics, vol.06,2008, pp.63-69.

[10] L. L. Feng, F. Lin and J. L. Xu, "Nature of property rights, ownership concentration and social responsibility fulfillment," Journal of Shanxi Finance and Economics University, vol.9, 2011, pp.100-107.

[11] J. Frooman, "Socially irresponsible and illegal behavior and shareholder wealth meta-analysis of event studies," Business and Society, vol.3, 1997, pp.221-249.

[12] M. S. Schwartz and A.B. Carroll, "Corporate social responsibility: a three-domain approach,” Business Ethics $\begin{array}{lll}\text { Quarterly, } & \text { vol.13, 2003, } & \text { pp.503-530. }\end{array}$ 